\title{
Bone Morphogenetic Proteins and Signaling Pathway in Inflammatory Bowel Disease
}

\author{
Ivana Maric ${ }^{1}$, Tamara Turk Wensveen ${ }^{2}$, Ivana Smoljan³, \\ Zeljka Crncevic Orlic ${ }^{2}$ and Dragica Bobinac ${ }^{1}$ \\ ${ }^{1}$ Department of Anatomy, Faculty of Medicine, University of Rijeka \\ ${ }^{2}$ Department of Internal Medicine, Clinical Hospital Rijeka \\ ${ }^{3}$ Psychiatric Hospital Rab \\ Croatia
}

\section{Introduction}

Inflammatory bowel disease (IBD) is a chronic, relapsing disease of the gastrointestinal (GI) tract of uncertain origin. Its two main phenotypes are Crohn's disease (CD) and ulcerative colitis (UC). CD affects any part of the GI tract and is characterized by transmural inflammation, whereas UC is confined to the colon and affects only the mucosal layer. IBD is thought to occur in genetically predisposed individuals that develop an abnormal immune response to enteric bacteria in the intestinal mucosa (Podolsky, 2002; Xavier RJ \& Podolsky, 2007). Disease occurs as a result of complex and dynamic interactions between immune and non-immune cells as well as the cross-talk between intestinal epithelium and mesenchyme (Danese, 2011; MacDonald et al., 2011; Strober \& Fuss, 2011). Therefore, factors that are able to influence both interactions may be very important for the pathogenesis and treatment of IBD.

Bone morphogenetic proteins (BMPs) are a large group of structurally related proteins that belong to the transforming growth factor- $\beta$ (TGF- $\beta$ ) superfamily. Along with their primarily osteogenic function their importance in development, proliferation and morphogenesis of a variety of cells and tissues has been shown (Hogan, 1996; Vukicevic et al., 1989; 1995; Wozney et al., 1988). In addition, association of BMPs with healing processes of different non-skeletal tissues and organs was also described (Lories et al., 2005; Martinovic et al., 2002; Nguyen et al., 2008; Simic \& Vukicevic, 2004; Turk et al., 2009; Vukicevic et al., 1996; Vukicevic \& Grgurevic, 2009). Due to their wide-range of effects, they are commonly named "body morphogenetic proteins" (Reddi, 2005). Perturbations in BMP expression and BMP signaling pathway have been associated with the pathological conditions linked to several human diseases such as inflammatory bowel disease (IBD) (Allaire et al., 2011; Burke et al., 2007; Krishnan et al., 2011).

In this chapter we will discuss the importance of BMPs in gut development and hereditary diseases as well as their influence on cellular and molecular events that occur in IBD and fibrogenesis, the most common complication of IBD. Furthermore, we will address the therapeutical potential of BMPs, especially BMP7 in treatment of IBD. Finally, we will explore the possibility of BMP pathway components as putative biomarkers of gut tumor development and progression. 


\section{Bone morphogenetic proteins}

BMPs comprise a group of very important signaling molecules, which is demonstrated by the the fact that several of these proteins, as well as their intracellular signaling components have been conserved in Drosophila and Caenorhabditis elegans. They are originally isolated from bone and major contribution to their isolation and characterization was made by Sampath and Reddi (Sampath \& Reddi, 1981; Sampath et al., 1987). BMPs are a large family within the transforming growth factor $\beta$ (TGF $\beta$ ) superfamily. Twenty BMP family members have been isolated and characterized so far. BMPs are divided into 4 groups based on their structure and function: the BMP2/4 group consists of BMP2, BMP4 and Decapentaplegic (dpp) in Drosophila, the OP-1 group is made up of BMP5, BMP6, BMP7 or osteogenic protein (OP1), BMP8 (OP2) and 60A in Drosophila, the GDF5 group includes the growthdifferentiation factor-5 (GDF5) or cartilage-derived morphogenetic protein-1 (CDMP1), GDF6 (CDMP2 or BMP13) and GDF7 (BMP12), and finally the forth group includes BMP9 and BMP10 (Miyazono, 2000; Miyazono et al., 2010). Grouping of BMPs is continually subject to changes due to studies which reveal their structure.

\section{BMPs}

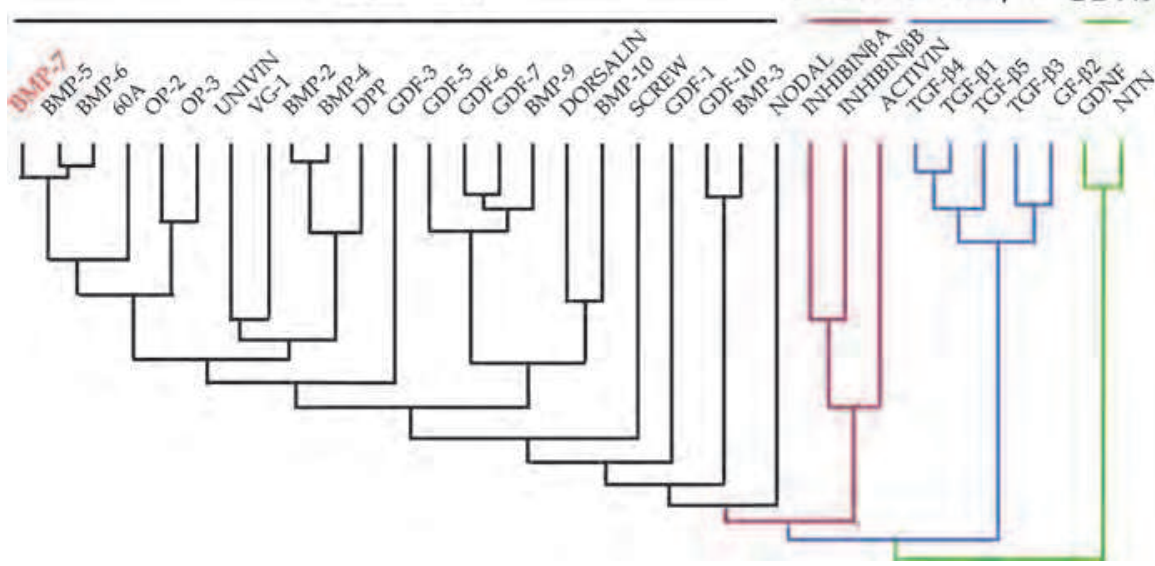

Fig. 1. TGF $\beta$ superfamily (according to Celeste et al., 1990).

BMPs are $30-38 \mathrm{kDa}$ dimeric molecules. Their structure is very important for biological activity in vivo. They are synthesized as large precursor proteins in the cytoplasm that are proteolytically processed to yield mature proteins (Kingsley, 1994). Mature BMP molecules are characterized by the formation of a cysteine knot with the seven conserved cysteine domains. Active form of the molecule is dimeric as a homodimer or heterodimer (Rueger, 2002).

BMPs transduce their signals by binding to two different transmembrane serine/threonine kinase receptors, type I (BMPRI) and type II (BMPRII). Three type I and three type II receptors are identified for BMP ligand binding (Fig. 2). Type I receptors include activin receptor type IA (ActRIA or ALK2) and BMP receptors type IA and IB (BRIA or ALK3; BRIB or ALK6), while type II receptors are BMP receptor type II (BRII), activin receptor type IIA and IIB (ActRIIA and ActRIIB) (Miyazono et al., 2005, Sieber et al., 2009). Receptors form 
heteromeric complexes and activate downstream signaling molecules through Smad and non-Smad signaling pathway (Fig. 3) (Korchynskyi \& ten Dijke, 2002; Massague et al., 2005; Miyazono et al., 2005). Both receptors are required to activate the signaling pathway. By BMP ligand binding, type II receptor phosphorylates the type I receptor which propagates the signal (Massague et al., 2005, Wrana et al., 1994).

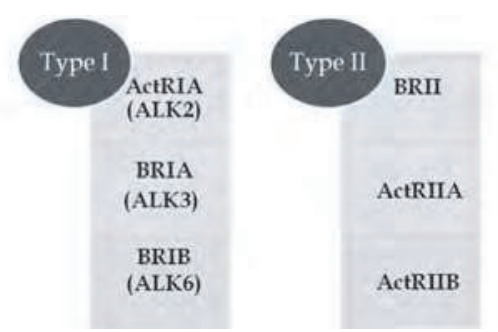

(a) BMP-receptors

\begin{tabular}{|c|c|c|}
\hline \multicolumn{3}{|c|}{ Smads } \\
\hline R-Smads & $\mathrm{Co}-\mathrm{Smad}$ & I-Smads \\
\hline $\begin{array}{c}\text { Smad } 1 / 5 / 8 \\
\text { Smad2/3 }\end{array}$ & Smad4 & $\begin{array}{l}\text { Smad6 } \\
\text { Smad7 }\end{array}$ \\
\hline
\end{tabular}

(b) BR-Smad and AR-Smad proteins

Fig. 2. Components of TGF $\beta / B M P$ signaling pathway

The intracellular mediators of BMP signaling transduction are Smad transcription factors. Smad is named after human Sma1 assessment and its identification with similar genes found in Drosophila (Drosophile mothers against dpp - Mad) and Caenorhabditis elegans (Sma) (Liu et al., 1996). Three subclasses of Smad proteins have been described based on their structure and function: receptor regulated Smads (R-Smads), common mediator Smad (co-Smad), and inhibitory Smads (I-Smads) (Fig. 2). R-Smads are further subdivided into BR-Smads referred to as BMP signaling (Smad1/5/8) and AR-Smads referred to as activin/TGF $\beta$ signaling $(\operatorname{Smad} 2 / 3)$. They are phyosphorylated by the type I receptors, interact with co-Smad (Smad4) and translocate into the nucleus initiating transcription of BMP response genes (Kawabata et al., 1998; Miyazono et al., 2010). Inhibitory Smads (ISmad6/7) compete with R-Smads for the activated type I receptor binding site. Smad7 inhibits both activin/TGF $\beta$ and BMP signaling pathway while Smad6 preferentially inhibits BMP signaling (Hanyu et al., 2001).

$\mathrm{BMP}$ signaling is controlled also by soluble BMP antagonists. They exert their function by direct binding of BMPs and prevent functional receptor/ligand interaction (Lein et al., 2002; Piccolo et al., 1996; Yanagita, 2005; Zimmerman et al., 1995). Several structurally distinct classes of inhibitory BMP binding proteins have been described in vertebrates: twisted gastrulation (TSG), chordin and noggin and the DAN-family of inhibitors. The DAN family includes a large number of members such as DAN, cerebrus, protein related to DAN and cerebrus (PRDC), gremlin, Cer1, USAG-1 and sclerostin (Bouwmeester et al., 1996; Hsu et al., 1998; Stanley et al., 1998). They bind different BMPs with various degrees of affinity and specifity. For instance, noggin and chordin bind BMP2 and -4 with higher affinity than BMP7 whereas sclerostin binds with greater affinity BMP6 and -7 (Lein et al., 2002; Yanagita, 2005).

\section{BMPs and their signaling pathway in gastrointestinal tract}

\subsection{BMPs and their signaling pathway in gastrointestinal tract development}

BMPs and their signaling pathways are important for the normal development of the gastrointestinal tract. They are active from the earliest stage of development and revealed to be essential for the intestinal growth and morphogenesis. It has also been shown that BMP 


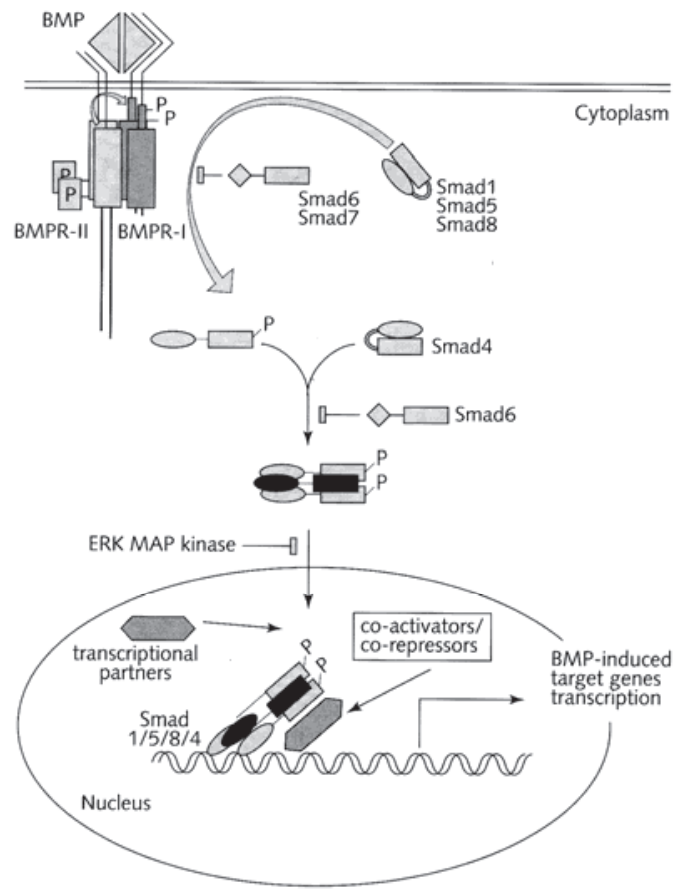

Fig. 3. BMP signaling pathway (with kind permission from Springer Science+Business

Media: Bone morphogenetic proteins: from laboratory, to clinical practice, Bone morphogentic protein receptors and their nuclear effectors in bone formation, 2002, pp. 3160, Korchynskyi, O. \& ten Dijke, P. Fig. 3)

signaling is a mediator in epithelial and mesenchymal stroma interaction which is required for the intestinal growth, morphogenesis, differentiation and homeostasis (Batts et al., 2006; de Santa Barbara et al., 2005). Initial investigation of the BMP expression in the GI tract showed limited expression of individual BMP and its receptors during development. BMP6 and BMP7 were found in the developing human and mouse intestine limiting its expression to the smooth muscle cells and intestinal epithelium, respectively (Helder et al., 1995; Perr et al., 1999). Expression of BMP type I receptor (ALK6) was found in the stomach and its pyloric region (Dewulf et al.,1995). It has also been noticed that villus formation depends on high BMP2 and -4 expressions in the condensed mesenchyme underlying sites of future villus formation and may inhibit crypt formation in the overlying epithelium (Karlsson et al., 2000). In addition, BMP2 and its receptors (IB and II) were expressed in the smooth muscle progenitors of mouse embryonic GI tract with evident BMP2-induced smooth muscle differentiation and phenotype (Goldman et al., 2009).

De Santa Barbara et al. (2005) noticed that the BMP signaling pathway showed wider expression than BMP ligands in the chick developing gut. This pathway is activated in all three tissue layers of the GI tract, allowing interaction and reciprocal communication. The BMP signaling activity was found in the mesoderm during the differentiation into visceral smooth muscle and was downregulated by the completion of this process. A similar observation was made for the enteric nervous system (ENS) during its derivation of the ectoderm. BMP 
signaling activity is detected also in the endoderm, future epithelium with prominent delay of $\mathrm{BMP}$ signaling activation in the colon. Inhibition of BMP activation by Bapx1 misexpression in the chick gut mesoderm results in diminished influence of mesoderm to endoderm-ectoderm signaling. This leads to an altered gut phenotype with marked muscular hypertrophy followed by abnormality in the ENS and epithelium. Decreased BMP signaling in mice overexpressing the BMP-antagonist noggin leads to abnormal villus morphogenesis of mouse proximal intestine. This was associated with stromal and epithelial hyperplasia, and ectopic crypt formation due to low levels of BmprIA and pSmad1/5/8 (Batts et al., 2006). A similar abnormal phenotype was found in the large intestine. These results suggest that BMP signaling restricts the site of crypt formation to the intervillus region and normally suppresses crypt formation in the villus. Human GI diseases which are accompanied by abnormal intestinal morphology, like JP or ENS disorder and even more chronic intestinal diseases associated with muscular hypertrophy such as Hirschprung's disease, could be associated with defects in the BMP signaling pathway (Amiel \& Lyonnet, 2001; He et al., 2004).

\subsection{BMPs and their signaling pathway in the normal gastrointestinal tract}

BMPs and their signaling pathway are expressed in normal intestine and colon. It was shown that BMP2, the BMP receptors (Ia, Ib, II), phosphorylated Smad1 and Smad4 are present in mature colonocytes at the epithelial surface of normal human and mouse colon (Hardwick et al., 2004). The expression of BMP receptors was also found in colonic epithelial cell lines and BMP2 treatment in vitro resulted in inhibition of proliferation and induction of apoptosis. BMPRIA and BMP2 are highly expressed in the villus epithelium and distal/surface epithelium of the adult mouse small and large intestine with increase expression in stroma and crypt epithelium (Batts et al., 2006; Haramis et al., 2004). BMP4 is expressed in stromal cells and mesenchimal cells surrounding the crypt and glands of the small and large intestine (Haramis et al., 2004; He et al., 2004).

The expression profile of genes in the mouse intestine showed a difference between the expression of BMP signaling components in the epithelium and mesenchyme (Li et al., 2007). BMP signaling is observed in both epithelial and mesenchymal compartments, though studies to date have primarily addressed epithelial signal transduction (He et al., 2004). BMP2, BMP4, BMP5, BMP6 and BMPRII are expressed in mesenchymal compartments while only BMP7 showed epithelial enrichment. BMP7 was present in surface epithelial cells and crypts of the normal colon mucosa (Grijelmo et al., 2007). BMP receptors type I (BMPRIA or ALK3 and Acvr1 or ALK2) are present in mesenchymal compartments while the expression of BMPRIB (ALK6) was found in both compartments. Smads are expressed in both epithelial and mesenchymal compartments with slight enrichments in the mesenchyme while Smad4 expression was approximately equal in both compartments. Along the colon crypt, a different pattern of Smad4 expression was observed with high expression in the zone of terminal differentiation (Korchynskyi et al., 1999).

Apart from noggin, the BMP pathway inhibitors are located exclusively in the mesenchyme. The gene expression analysis of normal human colon tops and basal crypts revealed difference in nine hundred and sixty-nine cDNA clones from these two compartments (Kosinski et al., 2007). BMP1, BMP2, BMP5, BMP7, SMAD7 and BMPRII were highly expressed in colon tops while expression of the BMP antagonists gremlin 1, gremlin 2 and chordin-like 1 was found in basal colon crypts originating from myofibroblasts and smooth muscle cells (Fig. 4). It was also shown that activation of extracellular calcium-sensing 
receptor (CaSR), expressed on the epithelia of the GI tract and myofibroblasts, downregulated BMP4 and noggin expression and raises the effective concentration of BMP2 leading to increased intestine repair and barrier development (Peiris et al., 2007).

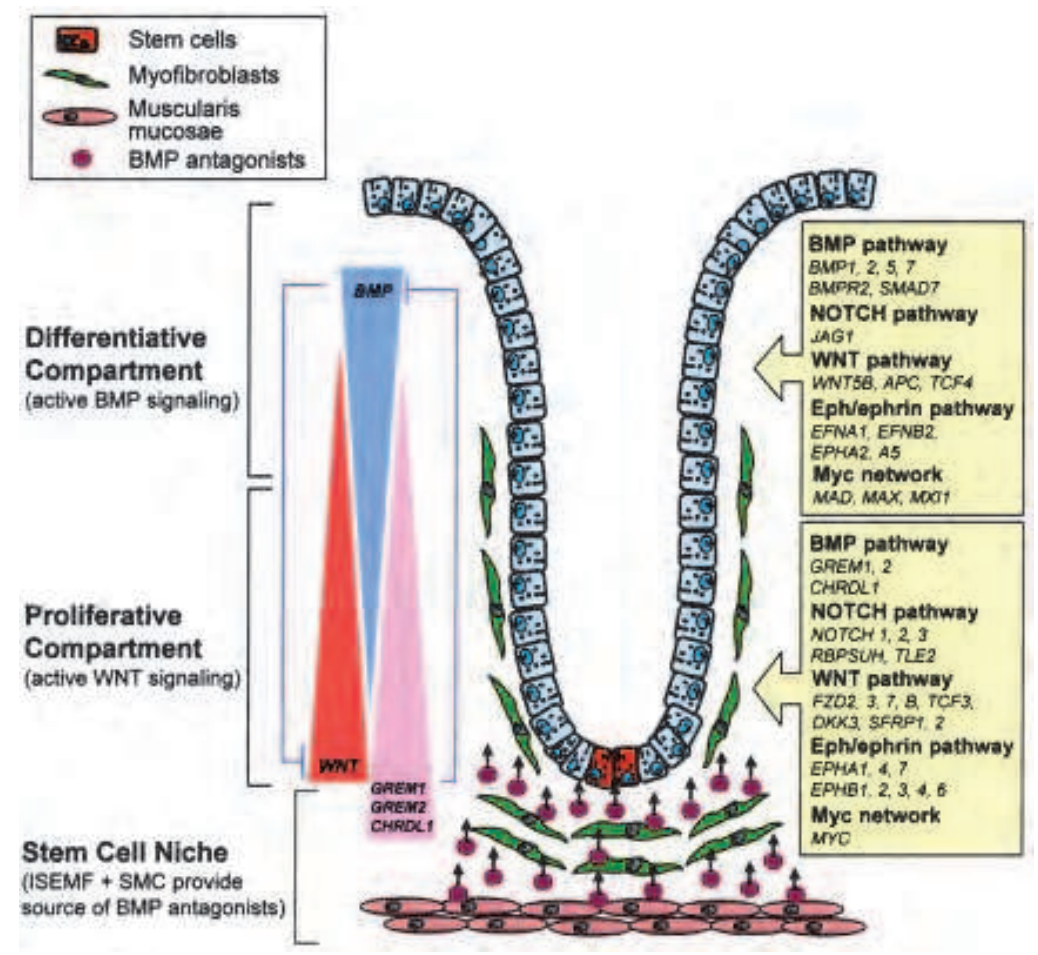

Fig. 4. BMP signaling components in compartments of the normal colon crypt (from Kosinski et al. (2007). Gene expression patterns of human colon tops and basal crypts and BMP antagonists as intestinal stem cell niche factors. Proc Natl Acad Sci USA 104:15418-

15423. Copyright (2007) National Academy of Science, U.S.A. Used with kind permission).

\subsection{BMPs and TGF $\beta$ /BMP signaling pathway in inflammatory bowel disease}

Animal models of colitis are often used to aid in IBD research. They allow a detailed examination of the pathological process from acute to chronic phase, providing an insight into the immunological disturbances behind the pathogenesis of IBD (Hibi et al., 2008; Mizoguchi \& Mizoguchi, 2010; Shi et al., 2011). In these animal models colitis can be induced by chemical, immunological, microbiological and physical factors (Boirivant et al., 1998; Morris et al., 1989; Okayasu et al., 1990). There are also transgenic and knock-out mouse strains that develop colitis, as well as spontaneous colitis models (Matsumoto et al., 1998; Mombaerts et al., 1993; Sadlack et al., 1993; Sundberg et al., 1994). Chemically induced colitis is one of the most utilized animal models. Dextran sulfate sodium (DSS), a heparin-like polysaccharide is often used to induce a UC-like colitis because of its simplicity and reproducibility of the inflammatory intestinal lesions. In the intestine of DSS treated mice epithelial barrier disruption with neutrophil and macrophage infiltration is observed as well as abnormal 
cytokine production (Dieleman et al., 1994; Kitajima et al., 1999). Trinitrobenzene sulfonic acid (TNBS) dissolved in ethanol induces a CD-like colitis, with transmural inflammation (Elson et al., 1995). Ethanol is thought to cause a transient increase in intestinal permeability, allowing TNBS to invade the musocal layers and act as a hapten to form complete antigens with tissue proteins. This provokes an intense and sustained inflammatory response and breaks T-cell tolerance to mucosal antigens (Boismenu \& Chen, 2000). Genetic colitis models such as gene knockout and transgene models offer another approach in experimental IBD research. They imply genetic modifications that favor the development of colitis. IL-2 deficient mice spontaneously develop a UC-like colitis in $100 \%$ of cases, while mice lacking the IL-10 gene develop chronic colitis only in the presence of enteric bacteria (Kuhn et al., 1993; Sadlack et al., 1993). Other genetic models include T cell receptor, STAT3 and IL-17 gene manipulation (Alonzi et al., 2004; Hibi et al., 2002; Mombaerts et al., 1993).

Monteleone et al. (2001) were among the first groups to show the disturbance of the TGF- $\beta 1$ signaling pathway in human IBD. They found that Smad7, an inhibitor of BMP-signaling, was overexpressed, whereas Smad3, an R-Smad of this signaling pathway, was downregulated. Due to Smad7 inhibition, lamina propria mononuclear cells (LPMC) isolated from mucosa of $\mathrm{CD}$ patients were not able to respond to TGF- $\beta 1$ and to downregulate proinflammatory cytokine expression, especially of TNFa and IFN $\gamma$. Moreover, Smad7 inhibition by specific antisense oligonucleotides allowed LPMC to respond to TGF- $\beta 1$ restoring TGF- $\beta 1$ signaling by increasing pSmad 3 and decreasing Smad7, and provide TGF- $\beta 1$-mediated inhibition of proinflammatory cytokine production in experimentally induced colitis (Boirivant et al., 2006). Previously, it was shown that mice with targeted disruption of the TGF- $\beta 1$ gene or one of its intracellular signaling components develop multifocal inflammation (Shull et al., 1992). High expression of Smad7, as seen in IBD mucosa, was a consequence of deregulated post-translational modification. Various proteins were shown to be involved, including Smurfs, the transcriptional coactivator p300, Arkadia and Jun activation domain-binding protein 1, which regulate Smad7 nuclear export and/or make the protein resistant to proteasome-mediated degradation (Monteleone et al., 2004a; 2004b; 2005). Targeted blocking of Smad7 gene expression was shown to be an effective way to attenuate the ongoing intestinal inflammation (Monteleone et al., 2008).

The R-Smad, Smad3 plays an important role in TGF $\beta$ signaling. Smad3 heterozygous mice, characterized by reduced levels of Smad3, showed accelerated healing of colonic mucosa after experimental induction of colitis with TNBS. The most prominent effects were on re-epithelization and proliferation of the intestinal epithelium, which was associated with reduced production of TGF- $\beta 1$ (Tokumasa et al., 2004). Another molecule of this pathway, CTGF, which acts as a downstream effector of the TGF $\beta$ signaling pathway, was markedly increased in almost $90 \%$ of CD tissue samples. CTGF expression is mostly localized in fibroblasts of the submucosal layer while completely lacking in inflammatory cells (di Mola et al., 2004). More recently, it has been reported that deficiency of Smad5 in intestinal epithelial cells leads to an increase of cell migration and villus lengthening followed by disassembly of the apical junctional complex (Allaire et al., 2011). This intestinal epithelial impairment makes Smad5 $5^{\Delta}$ IEC mice more susceptible to DSS colitis development and reduced healing. Decreased expression of the BR-Smad, Smad5 was also found in intestinal samples from IBD patients, which emphasizes the importance of BMP signaling in IBD.

Several growth factors like TGF $\beta$ superfamily, growth hormone, epidermal growth factor, keratinocyte growth factor, teduglutide and granulocyte macrophage/granulocite colony 
stimulating factors have been involved in clinical studies so far (Krishnan et al., 2010). BMPs as osteoinductive agents are mostly implemented in healing bone damage but the presence of their expression during development and in adulthood indicates their importance during different disease and healing processes. We have previously shown the accumulation of radioactively labeled BMP7 in the GI tract primarily in stomach and intestine with the highest uptake in terminal ileum (Fig. 5)(Maric et al., 2003).

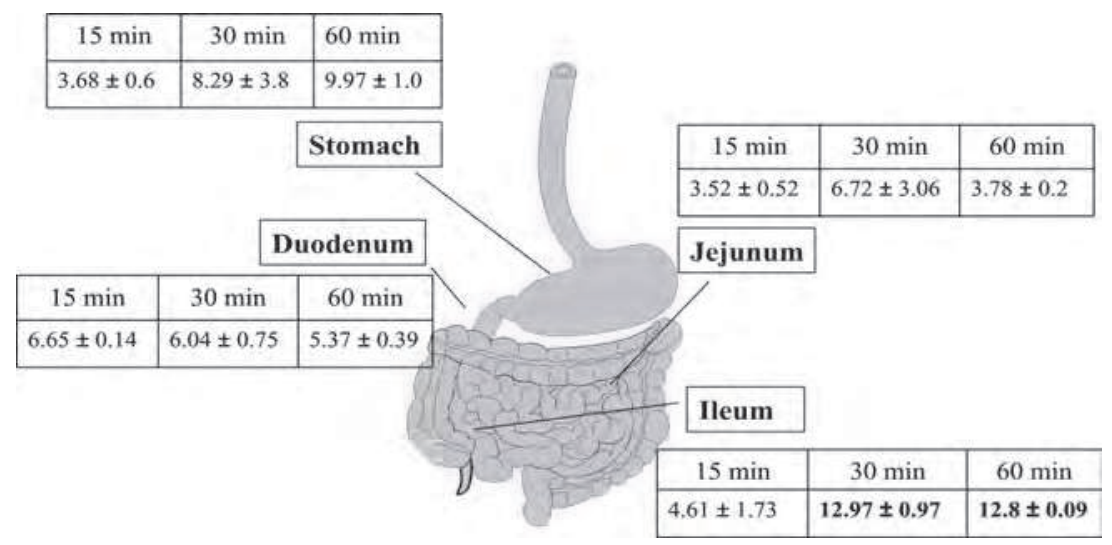

Fig. 5. Biodistrubution of $125 \mathrm{I}$-labeled BMP7 in rat gastrointestinal tract. Rats were analyzed at different time points following i.v. injection of 125I-BMP7 (injected dose was $25 \mu \mathrm{Ci} / 0.791$ $\mu \mathrm{g} / \mathrm{kg}$ ). Relative uptake of ${ }^{125} \mathrm{I}-\mathrm{BMP7}$ was expressed as ng of radiolabeled BMP7/g wet tissue weight (Maric et al., 2003).

In addition, systemically applied BMP7 reduced the macroscopic and microscopic changes observed in TNBS-induced colitis followed by downregulation of proinflammatory cytokines (i.e. IL-6, TNF $\alpha$, ICAM-1) and pro-fibrogenic cytokines (i.e. TGF $\beta$ ). BMP7 accelerated healing of wounded tissue and reduced neutrophil infiltration (Fig. 6, Fig. 7 \& Fig. 8).

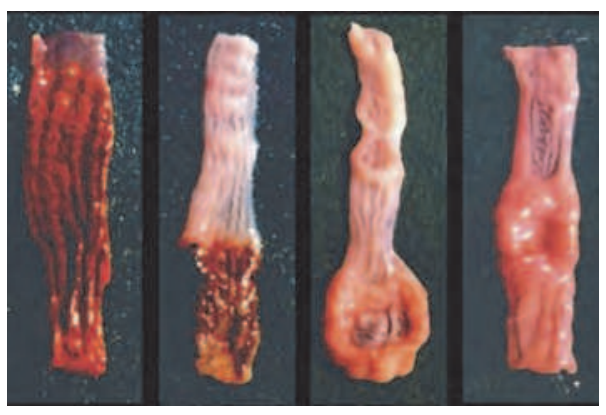

(a) TNBS-colitis

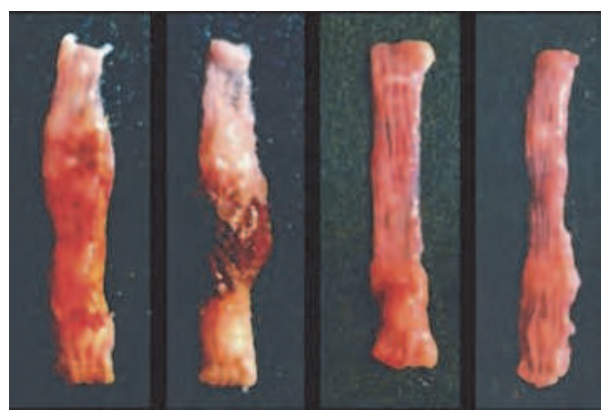

(b) TNBS-colitis upon BMP7 treatment

Fig. 6. Macroscopic appearance of colonic mucosa during different days of experimentally induced colitis. The cobblestone-like ulceration in acute (days 2 and 5) and linar ulceration in chronic (days 14 and 30) stage was evident in colon. BMP7, applied systemically reduced macroscopic colon damage. 


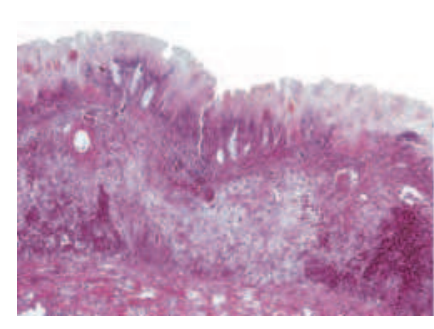

(a) Acute stage of colitis

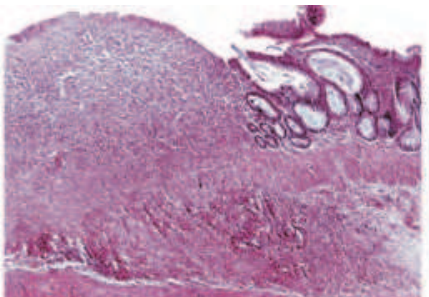

(b) Chronic stage of colitis

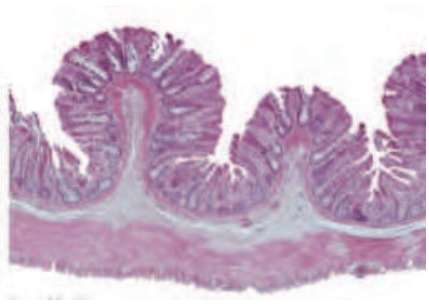

(c) BMP7 treatment

Fig. 7. Representative histological sections of colon from colitic rats treated with vehicle $(a, b)$ and BMP7 (c). Histologic findings in early stage of TNBS-colitis showed intensive inflammatory cell infiltration associated with colonic mucosa swelling and bleeding. In chronic stage of TNBS-colitis (b), diffuse infiltration with lymphocytes and fibroblasts was observed in ulcus region presenting healing process of colon tissue. The microstructure of colon was restored upon therapeutically application of BMP7 (c) Magnification x100.

BMP2 and BMP7 expression has been found in colon samples during acute and chronic stages of experimental colitis. BMP7 treatment slightly reduced the expression level of BMP2 (Maric et al., 2003; 2008). Beneficial effects of BMP7 were also observed in intestinal ischemia/reperfusion injury and fibrosis associated with chronic intestinal inflammation (Flier et al., 2010; Radhakrishnan et al., 2008).

\subsection{BMP and their pathway in intestinal fibrosis}

Intestinal fibrosis is a major complication of $\mathrm{CD}$ disease which is an outcome of multiple factors. It occurs as a result of different types of chronic inflammation, initiated in various cellular sources, but all result in deregulation of extracellular matrix turnover (Burke 2007, Fiocchi \& Lund, 2011). TGF $\beta$ is described as the most potent profibrotic factor of several

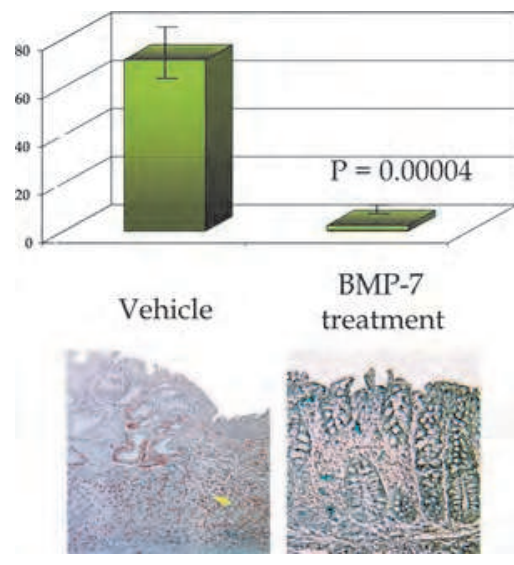

(a) PCNA staining
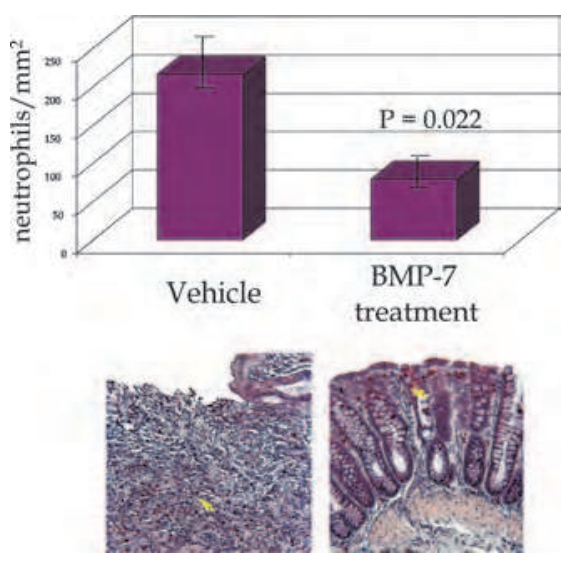

(b) Naphtol AS-D chloroacetate esterase staining

Fig. 8. Effect of BMP7 treatment on cell proliferation and neutrophil accumulation in TNBSinduced colitis. BMP7 significantly reduced cell proliferation and neutrophil accumulation upon 14-day long therapy. 
organs including organs of the GI tract. Experimental studies revealed that disruption of the TGF $\beta /$ Smad signaling pathway contributed to both chronic tissue inflammation and fibrosis (Flanders 2004; Nguyen \& Goldschmeding, 2008; Pucilowska et al., 2000; Rieder et al., 2007). Key molecules of this pathway are Smad3 and Smad7. Smad3 null mice exhibit a significant reduction of intestinal fibrosis, associated with increased intestinal expression of Smad7 and decreased expression of Smad3, CTGF, collagen I-III and TGF $\beta$ following TNBS induced colitis (Latella et al., 2009; Zanninelli et al., 2006,). Wild-type mice, on the other hand, showed decreased expression of Smad7 and increased expression of Smad3, similar to the findings of di Sabatino (2009) in biopsies of intestinal strictures from patients suffering from Crohn's disease. Myofibroblasts from mucosa underlying CD strictures produced significantly higher amounts of collagen induced by an increased expression of TGF $\beta$ and Smad2/3 but not Smad7 (di Sabatino et al., 2009). It was pointed out that a disturbance of TGF $\beta / B M P$ downstream signaling components could contribute to intestinal fibrosis and therefore they were presented as more specific antifibrotic targets than TGF $\beta$. Increased expression of TGF $\beta$, CTGF, collagen- $1 \alpha$, and BMP7 was found in strictured segments of CD intestinal biopsies (Burke et al., 2008), although previous studies showed anti-inflammatory and antifibrotic properties of BMP7 (Maric et al., 2003; Flier et al., 2010). The correlation between steroid treatment and stricture development in CD was also observed followed by increased expression of CTGF in both, in vivo and in vitro by stimulating intestinal fibroblasts (Burke et al., 2008). The capacity of BMP7 to antagonize the pro-fibrotic effects of TGF $\beta$ in various organs including the gut has recently been shown (Fiocchi, 1997; Flier et al., 2010; Zeisberg et al., 2005). Treatment with BMP7 inhibits intestinal fibrosis by downregulation of TNF and by inhibition of TGF $\beta$-induced epithelial to mesenchymal transition of the intestinal epithelial cells, which generates activated fibroblasts and contributes to intestinal fibrosis (Flier et al., 2010).

\subsection{BMP and their pathway in other gastrointestinal diseases}

Germline mutations in two members of the BMP pathway have been found to cause juvenile polyposis (JP). JP is an autosomal dominant hamartomatous polyposis syndrome. Affected individuals are predisposed to upper gastrointestinal and colorectal cancer. In almost half of the cases, patients have mutations or deletions in SMAD4 and BMPR1A genes (Howe et al., 1998; Houlston et al., 1998; Langeveld et al., 2010; van Hattem et al., 2008; WoodfordRichens et al., 2001; Zhou et al., 2001). Genetic linkage studies of JP patients revealed that Smad4 germline mutation was mapped to chromosome 18q21 while BMPR1A germline mutations were localized on chromosome 10q22-23 (Howe et al., 1998; 2001). In a genotypephenotype correlation study of JP patients, a significant prevalence of gastric polyposis was found in patients with Smad4 mutations when compared to other subsets of patients (Friedel et al., 2002). Histologically, JP polyps are characterized by dilated glands, abundant stroma and inflammatory infiltrates in a thickened lamina propria with normal epithelial covering (Howe et al., 2004). SMAD4 is a known tumor suppressor gene in pancreatic and colon cancer, but in JP it was hypothesized that SMAD4 gene acts as a susceptibility gene, a "gatekeeper", its loss of function resulting in polyp formation through indirect mechanisms, suggesting an important role of the stromal inflammatory response in the regulation of epithelial tumorigenesis (Moskaluk et al., 1997; Takagi et al., 1996). This theory was supported by a study on homozygous Smad4 knockout mice. The most important histological findings included thickened intestinal musoca with polyp formation, loss of 
villus architecture and expansion of the stroma with plasma cell infiltrates, while mice with conditional Smad4 deletion in the intestinal epithelial layer did not develop intestinal tumors (Kim et al., 2006). In contrast, polyps from JP patients with a germline SMAD4 mutation showed biallelic inactivation of SMAD4 in both the epithelium and stroma, suggesting a common clonal origin (Woodford-Richens et al., 2000).

Familial adenomatous polyposis (FAP) is an autosomal dominant syndrome characterized by hundreds to thousands of adenomatous colorectal polyps that are caused by a deletion in the adenomatous polyposis coli (APC) gene, localized on chromosome 5q21. Polyps develop in adolescence, and if not treated, malignant alteration inevitably occurs (Morton et al., 1993). Extraintestinal manifestations may also be present in form of osteomas, desmoid tumors, dental abnormalities and extracolonic cancer (Galiatsatos \& Foulkes, 2006). APC gene plays an important role in Wnt signaling and is involved in ubiquitine-mediated degradation of $\beta$ catenin. Functional defects of APC therefore lead to aberrant Wnt pathway activity, resulting in uncontrolled cell proliferation (Rustgi et al., 2007). In intestinal homeostasis, BMP molecules have a suppresive effect on Wnt- $\beta$-catenin pathway and preserved BMP signaling is required for inhibition of intestinal stem cell proliferation and repression of polyp formation (He et al., 2004; Haramis et al., 2004). Conversely, higher expression of Wnt signaling molecules in FAP results in BMP signaling downregulation. In a study on Wnt target genes, in APC mutant mice heterozygous for an allele equivalent to a human APC mutation, more severe polyposis and faster rate of tumor growth was associated with higher expression of the BMP antagonist Gremlin 1 and lower BMP2 and BMP4 expression (Lewis et al., 2010). Analogous results were found in human FAP tissue specimens, with BMP2 expression lost in dysplatic epithelium of mycroadenomas (Hardwick et al., 2004).

Association of JP and FAP with the BMP signaling pathway was confirmed by experiments on BMP-transgenic mice. Transgenic mice which overexpressed the BMP anatagonist noggin or mice with conditional inacativation of BMPRIA which led to disruption of both epithelial and mesenchymal BMP signaling, showed highly increased formation of intestinal polyps morphologically similar to those in JP (Haramis et al., 2004; He et al., 2004). Loss of mesenchymal BMP signaling by conditional inactivation of BMPRII in stroma led to intestinal bleeding, thickness of mucosa due to epithelial hyperplasia and myofibroblast increment and multiple hemartomatous polyp appearance (Beppu et al., 2008; Hardwick et al., 2008). These expression patterns found in human polyposis syndromes indicate that altered BMP expression plays an important role in uncontrolled cell proliferation and tumorigenesis in the intestine.

Finally, alteration of the BMP signaling pathway may be involved in the appearance of intestinal mucosal atrophy due to total parenteral nutrition (Zhang et al., 2009). Expression of BMP2, BMP4, BMPRII and pSmad1/5/8 has been found to be increased in intestinal mucosa without differences in BMP antagonist expression following parenteral nutrition. These alterations were suggested to affect epithelial cell proliferation.

\subsection{BMPs and their pathway in gastrointestinal cancers}

Extensive research was conducted to explore the genes and factors that may trigger the initiation and progression of colorectal cancers (Ulman \& Itzkowitz, 2011). Among a small number of genes known to affect cancer development, BMPs and their signaling pathway have been under intensive research during the last decade (van den Brink \& Offerhaus, 2007). So far, studies have revealed contradictory findings. Some of them have shown reduced or complete loss of BMP signaling, while others have shown increased expression of this pathway. 
Deregulation of mechanisms controlling expression of Smads was found in human colorectal cancers characterized by selective up-regulation of R-Smads in tumor cells and absence of Smad expression in tumor stroma (Korchynskyi et al., 1999). Co-Smad and ISmad were expressed in both tumor and normal tissues. BMP2, BMP3 and BMP7 have been found to be growth suppressive for colorectal cancer cells (Beck et al., 2006; Hardwick et al., 2004; Loh et al., 2008). BMP2 exerts growth suppression by increasing p21 ${ }^{\text {WAF1 }}$ protein levels, inducing p21WAF1 stabilization and not its transcription (Back et al., 2007). BMP/Smad independent pathways, like the RAS/ERK-mediated signaling cascade, interferes with BMP2-induced p21WAF1 stabilization, thus acting as a negative regulator of BMP signaling and arresting growth suppression. The expression of BMPRIA and pSmad1 was found in human colon cancer specimens as well as in several cell lines (Beck et al., 2006). The consequence of the loss of normal feedback inhibition could be seen in the intestinal epithelial cells in JP, where the absence of BMP signaling may lead to enhanced production of BMPs in the lamina propria or in epithelial cells (van den Brink, 2004). In addition, the loss of BMP signaling could also be connected with tumor progression. BMP4 and BMP7 expression has been found to increase with progression of the adenoma-carcinoma sequence and to correlate with a worse prognosis (Deng et al., 2007, Motoyama et al., 2008). The comparison of human adenoma and colorectal cancer specimens revealed the loss of active BMP signaling pathway in $9.1 \%$ and $77.7 \%$, respectively, (Kodach et al., 2007; 2008a) which correlated with tumor progression from late adenoma to early carcinoma. The most prominent finding was the loss of BMPRII and Smad4 expression in colorectal carcinoma (Hardwick et al., 2008; Kodach et al., 2007; 2008a) which was confirmed by similar findings in sporadic colorectal carcinoma. The loss of BMPRII expression was strictly correlated with microsatellite instability (Kodach et al., 2008b). On the other hand, it was noticed that BMP signaling was regained in more advanced tumor stages (Kodach et al., 2008a).

Significantly higher BMP7 expression was found in human colorectal cancer than in normal tissues. This expression correlated with parameters of pathological aggressiveness and poorest prognosis (Motoyama et al., 2008). BMP7 showed a divergent role in different pathological changes of colon mucosa (Grijelmo et al., 2007). Whether proinvasive or protective activity will prevail depends on the activity of inflammation, tumor type and grade and the status of the BMP-Smad dependent and independent pathways. BMP7 and its receptors are expressed in normal human colon crypts, aberrant crypt foci in sigmoiditis and in half of colorectal tumors. It is involved in cellular scattering and invasion of premalignant and carcinoma colon epithelial cells probably by BMP-Smad independent pathways. Recent studies have re-emphasized the influence of intact BMP signaling on tumor growth as well as on survival and proliferation of colon carcinoma cells in vivo and in vitro (Lorente-Trigos et al., 2010). The different levels of BMPs (BMP2, BMP4), Smad proteins (Smad1, Smad4, Smad5, and Smad8) and absence of BMP inhibitor (chordin and gremlin) expression was found in advanced sporadic colon carcinomas. Proliferation and tumor growth of primary colon carcinoma cells in vivo can be influenced by altering the activity of BMPRIB. An increase in this activity leads to enhanced tumor growth while its inhibition yields the opposite effect. In this respect BMPs, as members of TGF $\beta$ superfamily, resemble the TGF $\beta$ signaling pathway in sporadic colorectal cancer (Akiyama et al., 1996; Markowitz et al., 1995).

\section{Conclusion}

BMPs play a vital role in embryogenesis and in tissue homeostasis of numerous organs including the GI tract and their malfunction may cause different human disorders. 
Ubiquitous presence of BMPs and their importance in regeneration of many tissues aroused their name from bone morphogenetic protein to body morphogenetic protein (Reddi $\mathrm{AH}$ 2005). The BMP pathway showed complexity by numerous ligands and their antagonists, downstream effectors and/or other signaling mediators. In addition, the interaction of the BMP pathway with other signaling cascades adds another level of regulation.

Animal models of IBD provide a valuable tool in IBD research, and are detrimental for the understanding of the role of BMP signaling in this family of diseases. Since they are readily available and reproducible, they contribute greatly to our knowledge of the complex mechanisms of this chronic and debilitating disease and also facilitate the development of new therapeutic modalities.

The BMPs play an important role in a multitude of physiological processes and alterations in their signaling properties have been associated with various diseases. These include the majority of pathologies of the gastrointestinal tract, among which Crohn's disease, ulcerative colitis and various GI cancers. Not surprisingly, BMP signaling has been under extensive investigation as a therapeutic target. We, for example, have previously shown the beneficial effects of BMP7 therapy in an experimental model for colitis, with both anti-inflammatory and antifibrotic effects on colon damage. In addition, possible targets of the BMP signaling pathway for the prevention or treatment of IBD are Smad proteins, including Smad3, Smad5 or Smad7. However, many of the molecular mechanisms behind their functions are yet to be revealed and are currently under our and other people's investigation.

In summary, the BMP signaling pathway plays a major role in GI diseases and we therefore present it as a group of molecules of high clinical potential for the future.

\section{References}

Akiyama, Y.; Iwanaga, R.; Ishikawa, T.; Sakamoto, K.; Nishi, N.; Nihei, Z.; Iwama, T.; Saitoh, K. \& Yuasa Y. (1996). Mutations of the transforming growth factor-beta type II receptor gene are strongly related to sporadic proximal colon carcinomas with microsatellite instability. Cancer, Vol.78, No.12, pp. 2478-2484.

Allaire, J.M.; Darsigny, M.; Marcoux, S.S.; Roy, S.A.; Schmouth, J.F.; Umans, L.; Zwijsen, A.; Boudreau, F. \& Perreault, N. (2011). Loss of Smad5 leads to the disassembly of the apical junctional complex and increased susceptibility to experimental colitis. Am J Physiol Gastrointest Liver Physiol., Vol.300, No.4, pp. G586-G597.

Alonzi, T.; Newton, I.P.; Bryce, P.J.; Di Carlo, E.; Lattanzio, G.; Tripodi, M.; Musiani, P. \& Poli, V. (2004). Induced somatic inactivation of STAT3 in mice triggers the development of a fulminant form of enterocolitis. Cytokine, Vol.26, No.2, pp.45- 56.

Amiel, J. \& Lyonnet, S. (2001). Hirschsprung disease, associated syndromes, and genetics: a review. J Med Genet., Vol.38, No.11, pp.729-739.

Batts, L.E.; Polk, D.B.; Dubois, R.N. \& Kulessa, H. (2006). Bmp signaling is required for intestinal growth and morphogenesis. Dev Dyn., Vol.235, No.6, pp. 1563-1570.

Beck, S.E.; Jung, B.H.; Fiorino, A.; Gomez, J.; Rosario, E.D.; Cabrera, B.L.; Huang, S.C.; Chow, J.Y. \& Carethers, J.M. (2006). Bone morphogenetic protein signaling and growth suppression in colon cancer. Am J Physiol Gastrointest Liver Physiol., Vol.291, No.1, pp. G135-G145.

Beck, S.E.; Jung, B.H.; Del Rosario, E.; Gomez, J. \& Carethers, J.M. (2007). BMP-induced growth suppression in colon cancer cells is mediated by p21WAF1 stabilization and modulated by RAS/ERK. Cell Signal., Vol.19, No.7, pp. 1465-1472. 
Beppu, H.; Mwizerwa, O.N.; Beppu, Y.; Dattwyler, M.P.; Lauwers, G.Y.; Bloch, K.D. \& Goldstein AM. (2008). Stromal inactivation of BMPRII leads to colorectal epithelial overgrowth and polyp formation. Oncogene, Vol.27, No.8, pp. 1063-1070.

Bevan, S.; Woodford-Richens, K.; Rozen, P.; Eng, C.; Young, J.; Dunlop, M. \& al. (1999). Screening SMAD1, SMAD2, SMAD3, and SMAD5 for germline mutations in juvenile polyposis syndrome. Gut, Vol.45, No.3, pp. 406-408.

Boirivant, M.; Fuss, I.J.; Chu, A. \& Strober, W. (1998). Oxazolone colitis: A murine model of T helper cell type 2 colitis treatable with antibodies to interleukin 4. J Exp Med., Vol.188, No.10, pp.1929-1939.

Boirivant, M.; Pallone, F.; Di Giacinto, C.; Fina, D.; Monteleone, I.; Marinaro, M.; Caruso, R.; Colantoni, A.; Palmieri, G.; Sanchez, M.; Strober, W.; MacDonald, T.T. \& Monteleone, G. (2006). Inhibition of Smad7 with a specific antisense oligonucleotide facilitates TGF-beta1-mediated suppression of colitis. Gastroenterology, Vol.131, No.6, pp. 1786-1798.

Boismenu R \& Chen Y. (2000). Insights from mouse models of colitis. J Leukoc Biol., Vol.67, No.3, pp. 267-278.

Bouwmeester, T.; Kim, S.; Sasai, Y.; Lu, B. \& De Robertis, E.M. (1996). Cerberus is a headinducing secreted factor expressed in the anterior endoderm of Spemann's organizer. Nature, Vol.382, No.6592, pp. 595-601.

Burke, J.P.; Ferrante, M.; Dejaegher, K.; Watson, R.W.; Docherty, N.G.; De Hertogh, G.; Vermeire, S.; Rutgeerts, P.; D'Hoore, A.; Penninckx, F.; Geboes, K.; Van Assche, G. \& O'Connell, P.R. (2008). Transcriptomic analysis of intestinal fibrosis- associated gene expression in response to medical therapy in Crohn's disease. Inflamm Bowel Dis., Vol.14, No.9, pp. 1197-1204.

Burke, J.P.; Mulsow, J.J.; O'Keane, C.; Docherty, N.G.; Watson, R.W. \& O'Connell, P.R. (2007). Fibrogenesis in Crohn's disease. Am J Gastroenterol., Vol.102, No.2, pp. 439448.

Centrella, M.; Horowitz, M.C. ; Wozney, J.M. \& McCarthy, T.L. (1994). Transforming growth factor- $\beta$ gene family members and bone. Endocr Rev., Vol. 15, No.1, pp. 27-39. Danese, S. (2011). Immune and nonimmune components orchestrate the pathogenesis of inflammatory bowel disease. Am J Physiol Gastrointest Liver Physiol., Vol.300, No.5, pp. G716-G722.

Deng, H.; Ravikumar, T.S. \& Yang, W.L. (2007). Bone morphogenetic protein-4 inhibits heatinduced apoptosis by modulating MAPK pathways in human colon cancer HCT116 cells.Cancer Lett., Vol.256, No.2, pp.207-217.

De Santa Barbara, P.; Williams, J.; Goldstein, A.M.; Doyle, A.M.; Nielsen, C.; Winfield, S.; Faure, S. \& Roberts, D.J. (2005). Bone morphogenetic protein signaling pathway plays multiple roles during gastrointestinal tract development. Dev Dyn., Vol.234, No.2, pp. 312-322.

Dewulf, N.; Verschueren, K.; Lonnoy, O.; Morén, A.; Grimsby, S.; Vande Spiegle, K.; Miyazono, K.; Huylebroeck, D. \& Ten Dijke, P. (1995). Distinct spatial and temporal expression patterns of two type I receptors for bone morphogenetic proteins during mouse embryogenesis. Endocrinology., Vol.136, No.6, pp. 2652-2663.

Dieleman, L.A.; Ridwan, B.U.; Tennyson, G.S.; Beagley, K.W.; Bucy, R.P. \& Elson, C.O. (1994). Dextran sulfate sodium-induced colitis occurs in severe combined immunodeficient mice. Gastroenterology, Vol.107, No.6, pp.1643-1652. 
di Mola, F.F.; Di Sebastiano, P.; Gardini, A.; Innocenti, P.; Zimmermann, A.; Büchler, M.W. \& Friess, H. (2004). Differential expression of connective tissue growth factor in inflammatory bowel disease. Digestion, Vol.69, No.4, pp. 245-253.

Di Sabatino, A.; Jackson, C.L.; Pickard, K.M.; Buckley, M.; Rovedatti, L.; Leakey, N.A.; Picariello, L.; Cazzola, P.; Monteleone, G.; Tonelli, F.; Corazza, G.R.; MacDonald, T.T. \& Pender, S.L. (2009). Transforming growth factor beta signalling and matrix metalloproteinases in the mucosa overlying Crohn's disease strictures. Gut, Vol.58, No.6, pp. 777-789.

Elson, C.O.; Sartor, R.B.; Tennyson, G.S. \& Riddell, R.H. (1995). Experimental models of inflammatory bowel disease. Gastroenterology, Vol.109, No.4, pp. 1344-1367.

Fiocchi, C. (1997). Intestinal inflammation: a complex interplay of immune and nonimmune cell interactions. Am J Physiol., Vol.273, No.4 Pt 1, pp. G769-G775.

Fiocchi, C. \& Lund, P.K. (2011). Themes in fibrosis and gastrointestinal inflammation. Am J Physiol Gastrointest Liver Physiol., Vol.300, No.5, pp. G677-G683.

Flanders, K.C. (2004). Smad3 as a mediator of the fibrotic response. Int J Exp Pathol., Vol.85, No.2, pp.47-64.

Flier, S.N.; Tanjore, H.; Kokkotou, E.G.; Sugimoto, H.; Zeisberg, M. \& Kalluri, R. (2010). Identification of epithelial to mesenchymal transition as a novel source of fibroblasts in intestinal fibrosis. J Biol Chem., Vol.28, No.26, pp.20202-20212.

Friedl, W.; Uhlhaas, S.; Schulmann, K.; Stolte, M.; Loff, S.; Back, W.; Mangold, E.; Stern, M.; Knaebel, H.P.; Sutter, C.; Weber, R.G.; Pistorius, S.; Burger, B. \& Propping, P. (2002). Juvenile polyposis: massive gastric polyposis is more common in MADH4 mutation carriers than in BMPR1A mutation carriers. Hum Genet., Vol.111, No.1, pp. 108-111.

Galiatsatos, P. \& Foulkes, W.D. (2006). Familial adenomatous polyposis. Am J Gastroenterol., Vol.101, No.2, pp. 385-398.

Goldman, D.C.; Donley, N. \& Christian, J.L. (2009). Genetic interaction between Bmp2 and Bmp4 reveals shared functions during multiple aspects of mouse organogenesis. Mech Dev.,, Vol.126, No.3-4, pp. 117-127.

Grijelmo, C.; Rodrigue, C.; Svrcek, M.; Bruyneel, E.; Hendrix, A.; de Wever, O. \& Gespach, C. (2007). Proinvasive activity of BMP-7 through SMAD4/src-independent and ERK/Rac/JNK-dependent signaling pathways in colon cancer cells. Cell Signal., Vol.19, No.8, pp. 1722-1732.

Hanyu, A.; Ishidou, Y.; Ebisawa, T.; Shimanuki, T.; Imamura, T. \& Miyazono, K. (2001). The $\mathrm{N}$ domain of Smad7 is essential for specific inhibition of transforming growth factor-beta signaling. J Cell Biol., Vol.155, No.6, pp. 1017-1027.

Haramis, A.P.; Begthel, H.; van den Born, M.; van Es, J.; Jonkheer, S.; Offerhaus, G.J. \& Clevers, H. (2004). De novo crypt formation and juvenile polyposis on BMP inhibition in mouse intestine. Science, Vol.303, No.5664, pp. 1684-1686.

Hardwick, J.C.; van Den Brink, G.R.; Bleuming, S.A.; Ballester, I.; Van Den Brande, J.M.; Keller, J.J.; Offerhaus, G.J.; Van Deventer, S.J. \& Peppelenbosch, M.P. (2004). Bone morphogenetic protein 2 is expressed by, and acts upon, mature epithelial cells in the colon. Gastroenterology, Vol.126, No.1, pp. 111-121.

Hardwick, J.C.; Kodach, L.L.; Offerhaus, G.J. \& van den Brink, G.R. (2008). Bone morphogenetic protein signaling in colorectal cancer. Nat Rev Cancer., Vol.8, No.10, pp. 806-812. 
He, X.C.; Zhang, J.; Tong, W.G.; Tawfik, O.; Ross, J.; Scoville, D.H.; Tian, Q.; Zeng, X.; He, X.; Wiedemann, L.M.; Mishina, Y. \& Li, L. (2004). BMP signaling inhibits intestinal stem cell self-renewal through suppression of Wnt-beta-catenin signaling. Nat Genet., Vol.36, No.10, pp. 1117-1121.

Helder, M.N.; Ozkaynak, E.; Sampath, K.T.; Luyten, F.P.; Latin, V.; Oppermann, H. \& Vukicevic, S. (1995). Expression pattern of osteogenic protein-1 (bone morphogenetic protein-7) in human and mouse development. J Histochem Cytochem., Vol.43, No.10, pp. 1035-1044.

Hibi, T.; Ogata, H. \& Sakuraba, A. Animal models of inflammatory boel disease. (2002). J Gastroenterol., Vol.37, No.6, pp. 409-417.

Hogan, BL. (1996). Bone morphogenetic proteins: multifunctional regulators of vertebrate development. Genes \& Dev., Vol.10, No.13, pp. 1580-1594.

Houlston, R.; Bevan, S.; Williams, A.; Young, J.; Dunlop, M.; Rozen, P.; Eng, C.; Markie, D.; Woodford-Richens, K.; Rodriguez-Bigas, M.A.; Leggett, B.; Neale, K.; Phillips, R.; Sheridan, E.; Hodgson, S.; Iwama, T.; Eccles, D.; Bodmer, W. \& Tomlinson, I. (1998). Mutations in DPC4 (SMAD4) cause juvenile polyposis syndrome, but only account for a minority of cases. Hum Mol Genet., Vol.7, No.12, pp. 1907-1912.

Howe, J.R.; Roth, S.; Ringold, J.C.; Summers, R.W.; Järvinen, H.J.; Sistonen, P.; Tomlinson, I.P.; Houlston, R.S.; Bevan, S.; Mitros, F.A.; Stone, E.M. \& Aaltonen, L.A. (1998). Mutations in the SMAD4/DPC4 gene in juvenile polyposis. Science, Vol.280, No.5366, pp. 1086-1088.

Howe, J.R.; Bair, J.L.; Sayed, M.G.; Anderson, M.E.; Mitros, F.A.; Petersen, G.M.; Velculescu, V.E.; Traverso, G. \& Vogelstein, B. (2001). Germline mutations of the gene encoding bone morphogenetic protein receptor $1 \mathrm{~A}$ in juvenile polyposis. Nat Genet., Vol.28, No.2, pp. 184-187.

Howe, J.R.; Sayed, M.G.; Ahmed, A.F.; Ringold, J.; Larsen-Haidle, J.; Merg, A.; Mitros, F.A.; Vaccaro, C.A.; Petersen, G.M.; Giardiello, F.M.; Tinley, S.T.; Aaltonen, L.A. \& Lynch, H.T. (2004). The prevalence of MADH4 and BMPR1A mutations in juvenile polyposis and absence of BMPR2, BMPR1B, and ACVR1 mutations. Med Genet., Vol.41, No.7, pp. 484-491.

Hsu, D.R.; Economides, A.N.; Wang, X.; Eimon, P.M. \& Harland, R.M. (1998). The Xenopus dorsalizing factor Gremlin identifies a novel family of secreted proteins that antagonize BMP activities. Mol Cell., Vol.1, No.5, pp. 673-683.

Karlsson, L.; Lindahl, P.; Heath, J.K. \& Betsholtz, C. (2000). Abnormal gastrointestinal development in PDGF-A and PDGFR- $\alpha$ deficient mice implicates a novel mesenchymal structure with putative instructive properties in villus morphogenesis. Development, Vol.127, No.16, pp. 3457-3466.

Kawabata, M.; Imamura. T. \& Miyazono, K. (1998). Signal transduction by bone morphogenetic proteins. Cytokine Growth Factor Rev., Vol.9, No.1, pp. 49-61.

Kim, B.G.; Li, C.; Qiao, W.; Mamura, M.; Kasprzak, B.; Anver, M.; Wolfraim, L.; Hong, S.; Mushinski, E.; Potter, M.; Kim, S.J.; Fu, X.Y.; Deng, C. \& Letterio, J.J. (2006). Smad4 signalling in T cells is required for suppression of gastrointestinal cancer. Nature, Vol.441, No.7096, pp. 1015-1019.

Kingsley, DM. (1994). The TGF-beta superfamily: new members, new receptors, and new genetic tests of function in different organisms. Genes Dev. Vol.8, No.2, pp. 133-146. 
Kitajima, S.; Takuma, S. \& Morimoto, M. (1999). Tissue distribution of dextran sulfate sodium (DSS) in the acute phase of murine DSS-induced colitis. J Vet Med Sci., Vol.61, No.1, pp. 67-70.

Kodach, L.L.; Bleuming, S.A.; Musler, A.R.; Peppelenbosch, M.P.; Hommes, D.W.; van den Brink, G.R.; van Noesel, C.J.; Offerhaus, G.J. \& Hardwick, J.C. (2008a). The bone morphogenetic protein pathway is active in human colon adenomas and inactivated in colorectal cancer. Cancer, Vol.112, No.2, pp. 300-306.

Kodach, L.L.; Wiercinska, E.; de Miranda, N.F.; Bleuming, S.A.; Musler, A.R.; Peppelenbosch, M.P.; Dekker, E.; van den Brink, G.R.; van Noesel, C.J.; Morreau, H.; Hommes, D.W.; Ten Dijke, P.; Offerhaus, G.J. \& Hardwick, J.C. (2008b). The bone morphogenetic protein pathway is inactivated in the majority of sporadic colorectal cancers. Gastroenterology, Vol.134, No.5, pp. 1332-1341.

Korchynskyi, O.; Landström, M.; Stoika, R.; Funa, K.; Heldin, C.H.; ten Dijke, P. \& Souchelnytskyi, S. (1999). Expression of Smad proteins in human colorectal cancer. Int J Cancer., Vol.82, No.2, pp.197-202.

Korchynskyi, O. \& ten Dijke, P. (2002). Bone morphogentic protein receptors and their nuclear effectors in bone formation. In: Bone morphogenetic proteins: from laboratory to clinical practice, S. Vukicevic, T.K. Sampath, (Ed.), 31-60, Birkhäuser Verlag AG, ISBN 3-7643-6509-9, Basel, Switzerland.

Kosinski, C.; Li, V.S.; Chan, A.S.; Zhang, J.; Ho, C.; Tsui, W.Y.; Chan, T.L.; Mifflin, R.C.; Powell, D.W.; Yuen, S.T.; Leung, S.Y. \& Chen, X. (2007). Gene expression patterns of human colon tops and basal crypts and BMP antagonists as intestinal stem cell niche factors. Proc Natl Acad Sci USA, Vol.104, No.39, pp. 15418-15423.

Krishnan, K.; Arnone, B. \& Buchman, A. (2011). Intestinal growth factor: potential use in the treatment of inflammatory bowel disease and their role in mucosal healing. Inflamm Bowel Dis., Vol.17, No.1, pp. 410- 422.

Kuhn, R.; Lohler, J.; Rennick, D.; Rajewsky, K. \& Muller, W. (1993). Interleukin-10-deficient mice develop chronic enterocolitis. Cell, Vol.75, No.2, pp. 263-274.

Langeveld, D.; van Hattem, W.A.; de Leng, W.W.; Morsink, F.H.; Ten Kate, F.J.; Giardiello, F.M.; Offerhaus, G.J. \& Brosens, L.A. (2010). SMAD4 immunohistochemistry reflects genetic status in juvenile polyposis syndrome. Clin Cancer Res., Vol.16, No.16, pp. 4126-4134.

Latella, G.; Vetuschi, A.; Sferra, R.; Zanninelli, G.; D'Angelo, A.; Catitti, V.; Caprilli, R.; Flanders, K.C. \& Gaudio, E. (2009). Smad3 loss confers resistance to the development of trinitrobenzene sulfonic acid-induced colorectal fibrosis. Eur J Clin Invest. Vol.39, No.2, pp. 145-156.

Lein, P.; Drahushuk, K.M. \& Higgins, D. (2002). Effects of bone morphogenetic proteins on neural tissues. In: Bone morphogenetic proteins: from laboratory to clinical practice, S. Vukicevic, T.K. Sampath (Ed.), 289-319, Birkäuser Verlag AG, ISBN 3-7643-6509-9, Basel, Switzerland.

Lewis, A.; Segditsas, S.; Deheragoda, M.; Pollard, P.; Jeffery, R.; Nye, E.; Lockstone, H.; Davis, H.; Clark, S.; Stamp, G.; Poulsom, R.; Wright, N. \& Tomlinson, I. (2010). Severe polyposis in Apc (1322T) mice is associated with submaximal Wnt signalling and increased expression of the stem cell marker Lgr5. Gut, Vol.59, No.12, pp. 1680-1686. 
Li, X.; Madison, B.B.; Zacharias, W.; Kolterud, A.; States, D. \& Gumucio, D.L. (2007). Deconvoluting the intestine: molecular evidence for a major role of the mesenchyme in the modulation of signaling cross talk. Physiol Genomics., Vol.29, No.3, pp. 290-301.

Liu, F.; Hata, A.; Baker, J.C.; Doody, J.; Cárcamo, J.; Harland, R.M. \& Massagué, J. (1996). A human Mad protein acting as a BMP-regulated transcriptional activator. Nature, Vol. 381, No.6583, pp. 620-623.

Lorente-Trigos, A.; Varnat, F.; Melotti, A. \& Ruiz i Altaba A. (2010). BMP signaling promotes the growth of primary human colon carcinomas in vivo. J Mol Cell Biol., Vol.2, No.6, pp. 318-332.

Loh, K.; Chia, J.A.; Greco, S.; Cozzi, S.J.; Buttenshaw, R.L.; Bond, C.E.; Simms, L.A.; Pike, T.; Young, J.P.; Jass, J.R.; Spring, K.J.; Leggett, B.A. \& Whitehall, V.L. (2008). Bone morphogenic protein 3 inactivation is an early and frequent event in colorectal cancer development. Genes Chromosomes Cancer, Vol.47, No.6, pp. 449-460.

Lories, R.J.; Derese, I. \& Luyten, F.P. (2005). Modulation of bone morphogenetic protein signaling inhibits the onset and progression of ankylosing enthesitis. J Clin Invest., Vol.115, No.6, pp. 1571-1579.

MacDonald, T.T.; Monteleone, I.; Fantini, M.C. \& Monteleone, G. (2011). Regulation of homeostasis and inflammation in the intestine. Gastroenterology, Vol.140, No.6, pp. 1768-1775.

Markowitz, S.; Wang, J.; Myeroff, L.; Parsons, R.; Sun, L.; Lutterbaugh, J.; Fan, R.S.; Zborowska, E.; Kinzler, K.W. Vogelstein B, et al. (1995). Inactivation of the type II TGF-beta receptor in colon cancer cells with microsatellite instability. Science, Vol.268, No.5215, pp. 1336-1338.

Maric, I.; Poljak, Lj.; Zoricic, S.; Bobinac, D.; Bosukonda, D.; Sampath, K.T. \& Vukicevic, S. (2003). Bone morphogenetic protein-7 reduces the severity of colon tissue damage and accelerates the healing of inflammatory bowel disease in rats. J Cell Physiol., Vol.196, No.2, pp. 258-264.

Maric, I.; Kucic, N.; Grahovac, B.; Bobinac, D. \& Vukicevic, S. (2008). Expression of bone morphogenetic protein -2 and -7 during experimental inflammatory bowel disease. Medicina Fluminensis, Vol.44, No.1, pp. 60-66.

Martinovic, S.; Borovecki, F.; Sampath, T.K. \& Vukicevic, S. (2002). Biology of bone morphogenetic proteins. In: Bone morphogenetic proteins: from laboratory to clinical practice, S. Vukicevic, T.K. Sampath (Ed.), 87-119, Birkäuser Verlag AG, ISBN 37643-6509-9, Basel, Switzerland.

Massague, J.; Seoane, J. \& Wotton, D. (2005). Smad transcription factors. Genes Dev., Vol.19, No.23, pp. 2783-2810.

Matsumoto, S.; Okabe, Y.; Setoyama, H.; Takayama, K.; Ohtsuka, J.; Funahashi, H.; Imaoka, A.; Okada, Y. \& Umesaki, Y. (1998). Inflammatory bowel disease-like enteritis and caecitis in a senescence accelerated mouse P1/Yit strain. Gut, Vol.43, No.1, pp. 7178.

Miyazono, K. (2000). TGF-beta signaling by Smad proteins. Cytokine Growth Factor Rev., Vol.11, No.1-2, pp. 15-22.

Miyazono, K.; Maeda, S. \& Imamura, T. (2005). BMP receptor signaling: transcriptional targets, regulation of signals, and signaling cross-talk. Cytokine Growth Factor Rev., Vol. 16, No.3, pp. 2512-63. 
Miyazono, K.; Kamiya, Y. \& Morikawa, M. (2010). Bone morphogenetic protein receptors and signal transduction. J Biochem., Vol.147, No.1, pp. 35-51.

Mizoguchi, A. \& Mizoguchi, E. (2010). Animal models of IBD: linkage to human disease. Curr Opin Pharmacol., Vol.10, No.5, pp. 578-587.

Mombaerts, P.; Mizoguchi, E.; Grusby, M.J.; Glimcher, L.H.; Bhan, A.K. \& Tonegawa, S. (1993). Spontaneous development of inflammatory bowel disease in T cell receptor mutant mice. Cell, Vol.75, No.2, pp. 275-282.

Monteleone, G.; Kumberova, A.; Croft, N.M.; McKenzie, C.; Steer, H.W. \& MacDonald, T.T. (2001). Blocking Smad7 restores TGF- $\beta 1$ signaling in chronic inflammatory bowel disease. J Clin Invest., Vol.108, No.4, pp. 523-526.

Monteleone, G.; Pallone, F. \& MacDonald, T.T. (2004). Smad7 in TGF- $\beta$-mediated negative regulation of gut inflammation. Trends Immunol., Vol.25, No.10, pp. 513-517.

Monteleone, G.; Mann, J.; Monteleone, I.; Vavassori, P.; Bremner, R.; Fantini, M.; Del Vecchio Blanco, G.; Tersigni, R.; Alessandroni, L.; Mann, D.; Pallone, F. \& MacDonald, T.T.(2004). A failure of transforming growth factor-beta1 negative regulation maintains sustained NF-kappaB activation in gut inflammation. J Biol Chem., Vol.279, No.6, pp. 3925-3932.

Monteleone, G.; Del Vecchio Blanco, G.; Monteleone, I.; Fina, D.; Caruso, R.; Gioia, V.; Ballerini, S.; Federici, G.; Bernardini, S.; Pallone, F. \& MacDonald, T.T. (2005). Posttranscriptional regulation of Smad7 in the gut of patients with inflammatory bowel disease. Gastroenterology, Vol.129, No.5, pp. 1420-1429.

Monteleone, G.; Boirivant, M.; Pallone, F. \& MacDonald, T.T. (2008). TGF-beta1 and Smad7 in the regulation of IBD. Mucosal Immunol., Vol.1, Suppl.1, pp. S50-S53.

Morris, G.P.; Beck, P.L.; Herridge, M.S.; Depew, W.T.; Szewczuk, M.R. \& Wallace, J.L. (1989). Hapten-induced model of colonic inflammation and ulceration in the rat colon. Gastroenterology, Vol.96, No.3, pp. 795-803.

Morton, D.G.; Macdonald, F.; Haydon, J.; Cullen, R.; Barker, G.; Hulten. M.; Neoptolemos, J.P.; Keighley, M.R. \& McKeown, C. (1993). Screening practice for familial adenomatous polyposis: the potential for regional registers. Br J Surg ., Vol.80, No.2, pp. 255-258.

Moskaluk, C.A.; Hruban, R.H.; Schutte, M.; Lietman, A.S.; Smyrk, T.; Fusaro, L.; Lynch, J.; Yeo, C.J.; Jackson, C.E.; Lynch, H.T. \& Kern, S.E. (1997). Genomic sequencing of DPC4 in the analysis of familial pancreatic carcinoma. Diagn Mol Pathol., Vol.6, No.2, pp. 85-90.

Motoyama, K.; Tanaka, F.; Kosaka, Y.; Mimori, K.; Uetake, H.; Inoue, H.; Sugihara, K. \& Mori, M. (2008). Clinical significance of BMP7 in human colorectal cancer. Ann Surg Oncol., Vol.15, No.5, pp. 1530-1537.

Nguyen, T.Q.; Roestenberg, P.; van Nieuwenhoven, F.A.; Bovenschen, N.; Li, Z.; Xu, L.; Oliver, N.; Aten, J.; Joles, J.A.; Vial, C.; Brandan, E.; Lyons, K.M. \& Goldschmeding, R. (2008). CTGF inhibits BMP-7 signaling in diabetic nephropathy. J Am Soc Nephrol., Vol.19, No.11, pp. 2098-2107.

Nguyen, T.Q. \& Goldschmeding, R. (2008). Bone morphogenetic protein-7 and connective tissue growth factor: novel targets for treatment of renal fibrosis? Pharm Res., Vol.25, No.10, pp. 2416-2426. 
Okayasu, I.; Hatakeyama, S.; Yamada, M.; Ohkusa, T.; Inagaki, Y. \& Nakaya, R. (1990). A novel method in the induction of reliable experimental acute and chronic ulcerative colitis in mice. Gastroenterology, Vol.98, No.3, pp. 694-702.

Peiris, D.; Pacheco, I.; Spencer, C. \& MacLeod, R.J. (2007). The extracellular calcium-sensing receptor reciprocally regulates the secretion of BMP-2 and the BMP antagonist Noggin in colonic myofibroblasts. Am J Physiol Gastrointest Liver Physiol., Vol.292, No.3, pp. G753-G766.

Perr, H.A.; Ye, J. \& Gitelman, S.E. (1999). Smooth muscle expresses bone morphogenetic protein (Vgr-1/BMP-6) in human fetal intestine. Biol Neonate., Vol.75, No.3, pp. 210-214.

Piccolo, S.; Sasai, Y.; Lu, B. \& De Robertis, E.M. (1996). Dorsoventral patterning in Xenopus: inhibition of ventral signals by direct binding of chordin to BMP-4. Cell, Vol.86, No.4, pp. 589-598.

Podolsky, DK. (2002). Inflammatory bowel disease. N Engl J Med., Vol.347, No.6, pp. 417429.

Pucilowska, J.B.; Williams, K.L. \& Lund, P.K. (2000). Fibrogenesis. IV. Fibrosis and inflammatory bowel disease: cellular mediators and animal models. Am J Physiol Gastrointest Liver Physiol., Vol.279, No.4, pp. G653-G659.

Radhakrishnan, R.S.; Radhakrishnan, G.L.; Radhakrishnan, H.R.; Xue, H.; Adams, S.D.; Moore-Olufemi, S.D.; Harting, M.T.; Cox, C.S. Jr. \& Kone, B.C. (2008). Pretreatment with bone morphogenetic protein-7 (BMP-7) mimics ischemia preconditioning following intestinal ischemia/reperfusion injury in the intestine and liver. Shock, Vol.30, No.5, pp. 532-536.

Reddi, A.H. (2005). BMPs: from bone morphogenetic proteins to body morphogenetic proteins. Cytokine Growth Factor Rev., Vol.16, No.3, pp. 249-250.

Rieder, F.; Brenmoehl, J.; Leeb, S.; Schölmerich, J. \& Rogler, G. (2007). Wound healing and fibrosis in intestinal disease. Gut, Vol.56, No.1, pp. 130-139.

Rueger, D.C. (2002). Biochemistry of bone morphogenetic proteins, In: Bone morphogenetic proteins. From laboratory to clinical practice, S. Vukicevic \& T.K. Sampath, (Ed.), 1-18, Birkhäuser Verlag, ISBN 3-7643-6509-9, Basel, Switzerland.

Rustgi, A.K. (2007). The genesis of hereditary colon cancer. Genes Dev., Vol.21, No.20, pp. 2525-2538.

Sadlack, B.; Merz, H.; Schorle, H.; Schimpl, A.; Feller, A.C. \& Horak, I. (1993). Ulcerative colitis-like disease in mice with a disrupted interleukin-2 gene. Cell, Vol.75, No.2, pp. 253-261.

Sampath, T.K. \& Reddi, A.H. (1981). Dissociative extraction and reconstitution of extracellular matrix components involved in local bone differentiation. Proc Natl Acad Sci USA, Vol.78, No.12, pp. 7599-7603.

Sampath, T.K.; Muthukumaran, N. \& Reddi, A.H. (1987). Isolation of osteogenin, an extracellular matrix-associated, bone-inductive protein, by heparin affinity chromatography. Proc Natl Acad Sci USA, Vol.84, No.20, pp. 7109-7113.

Shi, X.Z.; Winston, J.H. \& Sarna, S.K. (2011). Differential immune and genetic responses in rat models of Crohn's colitis and ulcerative colitis. Am J Physiol Gastrointest Liver Physiol., Vol.300, No.1, pp. G41-G51.

Shull, M.M.; Ormsby, I.; Kier, A.B.; Pawlowski, S.; Diebold, R.J.; Yin, M.; Allen, R.; Sidman, C.; Proetzel, G.; Calvin, D.; Annunziata, N. \& Doetschman, T. (1992).Targeted 
disruption of the mouse transforming growth factor-beta 1 gene results in multifocal inflammatory disease. Nature, Vol.359, No.6397, pp. 693-699.

Sieber, C.; Kopf, J.; Hiepen, C. \& Knaus, P. (2009). Recent advances in BMP receptor signaling. Cytokine Growth Factor Rev., Vol.20, No.5-6, pp. 343-355.

Simic, P. \& Vukicevic, S. (2004). Bone morphogenetic proteins in development. In: Bone morphogenetic proteins: regeneration of bone and beyond, S. Vukicevic, T.K. Sampath, (Ed.), 73-108, Birkäuser Verlag AG, ISBN 3-7643-7139-0, Basel, Switzerland.

Stanley, E.; Biben, C.; Kotecha, S.; Fabri, L.; Tajbakhsh, S.; Wang, C.C.; Hatzistavrou, T.; Roberts, B.; Drinkwater, C.; Lah, M.; Buckingham, M.; Hilton, D.; Nash, A.; Mohun, T. \& Harvey, R.P. (1998). DAN is a secreted glycoprotein related to Xenopus cerberus. Mech Dev., Vol.77, No.2, pp. 173-184.

Strober, W. \& Fuss, I.J. (2011). Proinflammatory cytokines in the pathogenesis of inflammatory bowel diseases. Gastroenterology, Vol.140, No.6, pp. 1756-1767.

Sundberg, J.P.; Elson, C.O.; Bedigian, H. \& Birkenmeier, E.H. (1994). Spontaneous, heritable colitis in a new substrain of $\mathrm{C} 3 \mathrm{H} / \mathrm{HeJ}$ mice. Gastroenterology, Vol.107, No.6, pp. 1726-1735.

Takagi, Y.; Kohmura, H.; Futamura, M.; Kida, H.; Tanemura, H.; Shimokawa, K. \& Saji, S. (1996). Somatic alterations of the DPC4 gene in human colorectal cancers in vivo. Gastroenterology, Vol.111, No.5, pp. 1369-1372.

Tokumasa, A.; Katsuno, T.; Tanaga, T.S.; Yokote, K.; Saito, Y. \& Suzuki, Y. (2004). Reduction of Smad3 accelerates re-epithelialization in a murine model of colitis. Biochem Biophys Res Commun., Vol.317, No.2, pp. 377-383.

Turk, T.; Leeuwis, J.W.; Gray, J.; Torti, S.V.; Lyons, K.M.; Nguyen, T.Q. \& Goldschmeding, R. (2009). BMP signaling and podocyte markers are decreased in human diabetic nephropathy in association with CTGF overexpression. J Histochem Cytochem., Vol.57, No.7, pp. 623-631.

Ullman, T.A. \& Itzkowitz, S.H. (2011). Intestinal inflammation and cancer. Gastroenterology, Vol.140, No.6, pp. 1807-1816.

van den Brink, G.R. (2004). Linking pathways in colorectal cancer. Nat Genet., Vol.36, No.10, pp. 1038-1039.

van den Brink, G.R \& Offerhaus, G.J. (2007). The morphogenetic code and colon cancer development. Cancer Cell, Vol.11, No.2, pp. 109-117.

van Hatten, W.A.; Brosens, L.A.; de Leng, W.W.; Morsink, F.H.; Lens, S.; Carvalho, R.; Giardiello, F.M. \& Offerhaus, G.J. (2008). Large genomic deletions of SMAD4, BMPR1A and PTEN in juvenile polyposis. Gut, Vol.57, No.5, pp. 623-627.

Vukicevic, S.; Luyten, F.P. \& Reddi, A.H. (1989). Stimulation of the expression of osteogenic and chondrogenic phenotype in vitro by osteogenin. Proc Natl Acad Sci USA, Vol.86, No.22, pp. 8793-8797.

Vukicevic, S.; Stavljenic, A. \& Pecina, M. (1995). Discovery and clinical applications of bone morphogenetic proteins. Eur J Clin Chem Clin Biochem., Vol.33, No.10, pp. 661-671.

Vukicevic, S.; Kopp, J.B.; Luyten, F.P. \& Sampath, T.K. (1996). Induction of kidney mesenchyme by osteogenic protein-1, (bone morphogenetic protein-7). Proc Natl Acad Sci USA, Vol.93, No.17, pp. 9021-9026.

Vukicevic, S. \& Grgurevic, L. (2009). BMP-6 and mesenchymal stem cell differentiation. Cytokine Growth Factor Rev., Vol.20, No.5-6, pp.:441-448. 
Woodford-Richens, K.; Williamson, J.; Bevan, S.; Young, J.; Leggett, B.; Frayling, I.; Thway, Y.; Hodgson, S.; Kim, J.C.; Iwama, T.; Novelli, M.; Sheer, D.; Poulsom, R.; Wright, N.; Houlston, R. \& Tomlinson, I. (2000). Allelic loss at SMAD4 in polyps from juvenile polyposis patients and use of fluorescence in situ hybridization to demonstrate clonal origin of the epithelium. Cancer Res., Vol.60, No.9, pp. 24772482.

Woodford-Richens, K.L.; Rowan, A.J.; Poulsom, R.; Bevan, S.; Salovaara, R.; Aaltonen, L.A.; Houlston, R.S.; Wright, N.A. \& Tomlinson, I.P. (2001). Comprehensive analysis of SMAD4 mutations and protein expression in juvenile polyposis: evidence for a distinct genetic pathway and polyp morphology in SMAD4 mutation carriers. Am J Pathol., Vol.159, No.4, pp. 1293-1300.

Wozney, J.M.; Rosen, V.; Celeste, A.J.; Mitsock, L.M.; Whitters, M.J.; Kriz, R.W.; Hewick, R.M. \& Wang, E.A. (1988). Novel regulators of bone formation: molecular clones and activities. Science, Vol.242, No.4885, pp. 1528-1534.

Wrana, J.L.; Attisano, L.; Wieser, R.; Ventura, F. \& Massagué, J. (1994). Mechanism of activation of the TGF-beta receptor. Nature, Vol.370, No.6488, pp. 341-347.

Xavier, R.J. \& Podolsky, D.K. (2007). Unravelling the pathogenesis of inflammatory bowel disease. Nature, Vol.448, No.7152, pp. 427-434.

Yanagita, M. (2005). BMP antagonists: their roles in development and involvement in pathophysiology. Cytokine Growth Factor Rev., Vol.16, No.3, pp. 309-317.

Zanninelli, G.; Vetuschi, A.; Sferra, R.; D'Angelo, A.; Fratticci, A.; Continenza, M.A.; Chiaramonte, M.; Gaudio, E.; Caprilli, R. \& Latella, G. (2006). Smad3 knock-out mice as a useful model to study intestinal fibrogenesis. World J Gastroenterol., Vol.12, No.8, pp. 1211-1218.

Zeisberg, M.; Shah, A.A. \& Kalluri, R. (2005). Bone morphogenic protein-7 induces mesenchymal to epithelial transition in adult renal fibroblasts and facilitates regeneration of injured kidney. J Biol Chem., Vol.280, No.9, pp. 8094-8100.

Zhang, C.; Feng, Y.; Yang, H.; Koga, H. \& Teitelbaum, D.H. (2009). The bone morphogenetic protein signaling pathway is upregulated in a mouse model of total parenteral nutrition. J Nutr., Vol.139, No.7, pp. 1315-1321.

Zhou, X.P.; Woodford-Richens, K.; Lehtonen, R.; Kurose, K.; Aldred, M.; Hampel, H.; Launonen, V.; Virta, S.; Pilarski, R.; Salovaara, R.; Bodmer, W.F.; Conrad, B.A.; Dunlop, M.; Hodgson, S.V.; Iwama, T., Jarvinen, H.; Kellokumpu, I.; Kim, J.C.; Leggett, B.; Markie, D.; Mecklin, J.P.; Neale, K.; Phillips, R.; Piris, J.; Rozen, P.; Houlston, R.S.; Aaltonen, L.A.; Tomlinson, I.P. \& Eng, C. (2001). Germline mutations in BMPR1A/ALK3 cause a subset of cases of juvenile polyposis syndrome and of Cowden and Bannayan-Riley-Ruvalcaba syndromes. Am J Hum Genet., Vol.69, No.4, pp. 704-711.

Zimmerman, L.B.; De Jesús-Escobar, J.M. \& Harland, R.M. (1996). The Spemann organizer signal noggin binds and inactivates bone morphogenetic protein 4. Cell, Vol.86, No.4, pp. 599-606. 


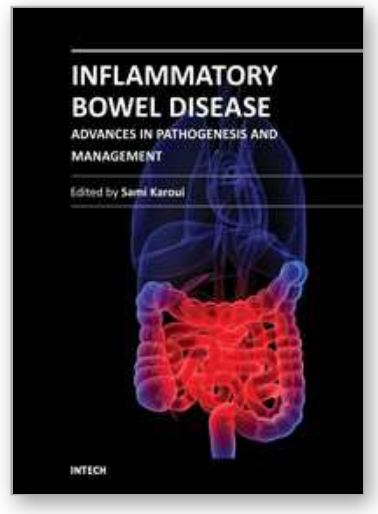

\author{
Inflammatory Bowel Disease - Advances in Pathogenesis and \\ Management \\ Edited by Dr. Sami Karoui
}

ISBN 978-953-307-891-5

Hard cover, 332 pages

Publisher InTech

Published online 27, January, 2012

Published in print edition January, 2012

This book is dedicated to inflammatory bowel disease, and the authors discuss the advances in the pathogenesis of inflammatory bowel disease, as well as several new parameters involved in the etiopathogeny of Crohn's disease and ulcerative colitis, such as intestinal barrier dysfunction and the roles of TH 17 cells and IL 17 in the immune response in inflammatory bowel disease. The book also focuses on several relevant clinical points, such as pregnancy during inflammatory bowel disease and the health-related quality of life as an end point of the different treatments of the diseases. Finally, advances in management of patients with inflammatory bowel disease are discussed, especially in a complete review of the recent literature.

\title{
How to reference
}

In order to correctly reference this scholarly work, feel free to copy and paste the following:

Ivana Maric, Tamara Turk Wensveen, Ivana Smoljan, Zeljka Crncevic Orlic and Dragica Bobinac (2012). Bone Morphogenetic Proteins and Signaling Pathway in Inflammatory Bowel Disease, Inflammatory Bowel Disease Advances in Pathogenesis and Management, Dr. Sami Karoui (Ed.), ISBN: 978-953-307-891-5, InTech, Available from: http://www.intechopen.com/books/inflammatory-bowel-disease-advances-in-pathogenesis-andmanagement/bone-morphogenetic-proteins-in-inflammatory-bowel-disease

\section{INTECH}

open science | open minds

\section{InTech Europe}

University Campus STeP Ri

Slavka Krautzeka 83/A

51000 Rijeka, Croatia

Phone: +385 (51) 770447

Fax: +385 (51) 686166

www.intechopen.com

\section{InTech China}

Unit 405, Office Block, Hotel Equatorial Shanghai

No.65, Yan An Road (West), Shanghai, 200040, China

中国上海市延安西路65号上海国际贵都大饭店办公楼 405 单元

Phone: +86-21-62489820

Fax: +86-21-62489821 
(C) 2012 The Author(s). Licensee IntechOpen. This is an open access article distributed under the terms of the Creative Commons Attribution 3.0 License, which permits unrestricted use, distribution, and reproduction in any medium, provided the original work is properly cited. 